\title{
Spectra of Positrons Lifetimes in Choose Gel Drugs
}

\author{
R. Pietrzak ${ }^{a, *}$, J. Muszyńska ${ }^{a}$ And A. KAJdas ${ }^{b}$ \\ ${ }^{a}$ Institute of Physics, Opole University \\ Oleska 48, 45-052 Opole, Poland \\ ${ }^{b}$ Centrum of Oncology - M. Skłodowska-Curie Institute \\ Wybrzeże Armii Krajowej 15, 44-101 Gliwice, Poland
}

\begin{abstract}
Spectra of positrons lifetimes in selected gel non-steride analgesic and antiphlogistic drugs were investigated. The basic components in them were sodium salts of diclophenac and they differed from one another with the chemical composition of other components. It was found that in all of the investigated spectra there occurred a component which testified to the formation of positronium. The differences in the values of ortho-Ps component lifetimes and their intensity can be attributed to the presence of ingredients modifying the effects of the drug.
\end{abstract}

PACS numbers: 78.70.Bj, 46.70.Hg

\section{Introduction}

Modern medicine makes a broad use of achievements of contemporary physics both for diagnostic and prophylactic purposes. Contemporarily applied medicaments are, generally, mixtures of a number of components and have a complicated chemical structure, a not yet thoroughly known physical one. A better recognition of the physical structure, e.g. the degree of filling up the space by chemical substances, creates a possibility of investigating them with additional components which possess required healing properties.

For several years now the technique of measuring positrons lifetimes has been used to determine empty spaces in liquids [1-5] and porous materials, including gels [6-20]. In the paper [21] the results of measurements of positrons lifetimes in medical preparations of insulin were presented, in which, applying the model of annihilation of ortho-Ps in empty spaces (as proposed by Tao [22] and Eldrup et al. [23]), we determined the radii of empty spherical spaces in preparations of different technologies of manufacture. We noticed as well the existence of correlation between the degree of filling up the space of the preparation and the time of maximal effectiveness of its performance in the human organism.

${ }^{*}$ corresponding author; e-mail: pietr@uni.opole.pl 
For pharmacists-technologists it is vital to determine the volume of empty spaces in the preparation, as well as their concentration, since it is possible to place, in these volumes, additional ingredients to accelerate or retard the activity of the drug, or those removing its side-effects. Investigations of positrons lifetimes spectra allow determination of radii of the empty spaces and their concentrations in the investigated porous preparations and gels.

The present paper is devoted to investigations of positrons lifetimes in selected non-steride analgesic and antiphlogistic drugs, in which healing substances, chiefly sodium salts of diclophenac, are dissolved in gels of differing chemical composition. Annihilation-oriented investigations proved that in all of the cases there was created positronium. Making the use of Wang's [24] and Kobyashi's [25] model, the radii of spherical "voids" were determined (with the assumption of their spherical shape), as well as the degree of filling up the space.

\section{Manner of measuring}

The drugs under investigation filled very tightly two plexiglass vessels being $7 \mathrm{~mm}$ deep and $20 \mathrm{~mm}$ in diameter (Fig. 1). The vessels were covered with hostaphonic foil of surface density of $0.9 \mathrm{mg} / \mathrm{cm}^{2}$. Between the vessels there was placed a source of ${ }^{22} \mathrm{Na}$ positrons, also covered with the above-mentioned foil. In

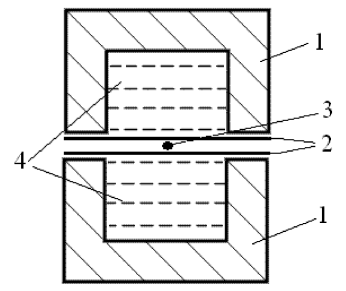

Fig. 1. A diagram of the apparatus to investigate annihilation of positrons in liquid dihexile ether: 1 - plexiglass vessels, 2 - hostaphonic foil, 3 - source of ${ }^{22} \mathrm{Na}$ positrons, 4 - medical preparation.

order to determine the positrons lifetimes in the investigated drugs a standard fast-slow spectrometer of $250 \mathrm{ps}$ resolution was used. The obtained spectra were analyzed following their distribution into two and three components by means of LIFE TIME [26] computer program. In the case of both distributions a component of lifetime of a few nanoseconds in length was found to occur, testifying to the annihilation of positrons from the state of bounded ortho-Ps.

\section{Results of the measurements}

The obtained spectra of positrons lifetimes were distributed into two or three components. It was found that in all of the cases the decomposition of the spectrum into three components yields a better value of the adjustment coefficient $\left(\chi^{2}\right)$ of 
experimental results to the assumed model than in the case of its decomposition into two components. An analysis of the obtained results points to the fact that in all the cases it was possible to isolate a component of lifetime of nanoseconds order, which testifies to positrons annihilation in the pick-off process of ortho-Ps localized in the empty space of the material. Therefore, further in the paper, we shall discuss the results concerning the ortho-Ps component of the spectrum of positrons lifetimes.

For all the investigated systems the mean lifetime $\tau_{\mathrm{m}}$ was also determined by means of the following formula:

$$
\tau_{\mathrm{m}}=\frac{\sum_{i} \tau_{i} I_{i}}{\sum_{i} I_{i}} .
$$

The results obtained for selected non-steride analgesic and antiphlogistic drugs of gel structure are displayed in Table. The healing components were: sodium salt of diclophenac, ketoprofen, naproxen, piroxicom, and phenylbenzene of different percentages.

TABLE

Parameters of the positron lifetime spectrum in the investigated preparations. $C$ means concentration. Standard deviations of measured quantities are given in round brackets.

\begin{tabular}{|c|c|c|c|c|c|c|c|c|c|c|c|}
\hline \multirow[t]{2}{*}{$\begin{array}{c}\text { Name of } \\
\text { drug }\end{array}$} & \multirow[t]{2}{*}{$\begin{array}{c}\text { Main } \\
\text { component }\end{array}$} & \multirow[t]{2}{*}{$\begin{array}{c}\text { Physical } \\
\text { form }\end{array}$} & \multirow[t]{2}{*}{$\begin{array}{c}C \\
{[\%]}\end{array}$} & \multicolumn{4}{|c|}{$\begin{array}{c}\text { Parameters of the spectrum } \\
\text { at two-component } \\
\text { distribution }\end{array}$} & \multicolumn{4}{|c|}{$\begin{array}{c}\text { Parameters of the spectrum } \\
\text { at three-component } \\
\text { distribution }\end{array}$} \\
\hline & & & & $\tau_{\mathrm{m}}[\mathrm{ps}]$ & $\tau_{2}[\mathrm{ps}]$ & $I_{2}[\%]$ & $\chi^{2}$ & $\tau_{\mathrm{m}}[\mathrm{ps}]$ & $\tau_{3}[\mathrm{ps}]$ & $I_{3}[\%]$ & $\chi^{2}$ \\
\hline $\begin{array}{c}\text { Feloran } \\
(1)\end{array}$ & $\begin{array}{c}\text { sodium salt } \\
\text { of diclophenac }\end{array}$ & gel & 1 & $\begin{array}{c}852.3 \\
(8.6)\end{array}$ & $\begin{array}{c}2804 \\
(20)\end{array}$ & $\begin{array}{l}20.85 \\
(0.11)\end{array}$ & 0.994 & $\begin{array}{l}847.4 \\
(18.6)\end{array}$ & $\begin{array}{c}2811 \\
(21)\end{array}$ & $\begin{array}{c}20.65 \\
(0.3) \\
\end{array}$ & 0.9961 \\
\hline $\begin{array}{c}\text { Nuklofen } \\
\text { (2) }\end{array}$ & $\begin{array}{c}\text { sodium salt } \\
\text { of diclophenac }\end{array}$ & gel & 1 & $\begin{array}{l}920.8 \\
(6.7)\end{array}$ & $\begin{array}{l}2893 \\
(16)\end{array}$ & \begin{tabular}{|l|}
22.84 \\
$(0.07)$
\end{tabular} & 1.1095 & $\begin{array}{l}887.4 \\
(12.3)\end{array}$ & $\begin{array}{l}2856 \\
(13)\end{array}$ & $\begin{array}{l}21.97 \\
(0.2)\end{array}$ & 1.1072 \\
\hline $\begin{array}{c}\text { Olfen } \\
(3)\end{array}$ & $\begin{array}{c}\text { sodium salt } \\
\text { of diclophenac }\end{array}$ & gel & 1 & $\begin{array}{c}973.13 \\
(3.1)\end{array}$ & $\begin{array}{l}3098 \\
(40)\end{array}$ & $\begin{array}{l}22.85 \\
(0.61)\end{array}$ & 1.0741 & $\begin{array}{l}1028.1 \\
(10.4)\end{array}$ & $\begin{array}{c}3364 \\
(8)\end{array}$ & \begin{tabular}{|l|}
22.71 \\
$(0.17)$
\end{tabular} & 1.129 \\
\hline $\begin{array}{c}\text { Ratiogel } \\
(4)\end{array}$ & $\begin{array}{c}\text { sodium salt } \\
\text { of diclophenac }\end{array}$ & gel & 1 & $\begin{array}{c}979.5 \\
(8.3)\end{array}$ & $\begin{array}{c}3181 \\
(18) \\
\end{array}$ & $\begin{array}{l}22.6 \\
(0.1)\end{array}$ & 1.0626 & $\begin{array}{l}1005.8 \\
(20.9) \\
\end{array}$ & $\begin{array}{l}3357 \\
(29) \\
\end{array}$ & $\begin{array}{l}22.18 \\
(0.28) \\
\end{array}$ & 1.0951 \\
\hline $\begin{array}{c}\text { Veral } \\
(5)\end{array}$ & $\begin{array}{c}\text { sodium salt } \\
\text { of diclophenac }\end{array}$ & & 1 & $\begin{array}{l}891.5 \\
(4.5)\end{array}$ & $\begin{array}{l}2913 \\
(12)\end{array}$ & $\begin{array}{l}21.38 \\
(0.04)\end{array}$ & 1.0832 & $\begin{array}{l}885.7 \\
(16.1)\end{array}$ & $\begin{array}{c}2930 \\
(16)\end{array}$ & $\begin{array}{l}21.12 \\
(0.26) \\
\end{array}$ & 1.0781 \\
\hline $\begin{array}{c}\text { Voltenac } \\
(6)\end{array}$ & $\begin{array}{c}\text { sodium salt } \\
\text { of diclophenac }\end{array}$ & gel & 1 & $\begin{array}{l}846.1 \\
(10.5)\end{array}$ & $\begin{array}{l}2858 \\
(16)\end{array}$ & $\begin{array}{l}20.26 \\
(0.18)\end{array}$ & 1.0863 & $\begin{array}{l}847.5 \\
(16.2)\end{array}$ & $\begin{array}{l}2860 \\
(22)\end{array}$ & $\begin{array}{l}20.28 \\
(0.24) \\
\end{array}$ & 1.0884 \\
\hline $\begin{array}{c}\text { Fastum } \\
(7)\end{array}$ & Ketoprofen & gel & 2.5 & $\begin{array}{l}842.6 \\
(37.9) \\
\end{array}$ & $\begin{array}{c}2956 \\
(58)\end{array}$ & $\begin{array}{l}18.87 \\
(0.79) \\
\end{array}$ & 1.0149 & $\begin{array}{l}831.9 \\
(17.9) \\
\end{array}$ & $\begin{array}{l}2930 \\
(15)\end{array}$ & $\begin{array}{c}18.7 \\
(0.23) \\
\end{array}$ & 0.9975 \\
\hline $\begin{array}{c}\text { Naproxen } \\
(8)\end{array}$ & & & 10 & $\begin{array}{l}723.1 \\
(9.1)\end{array}$ & $\begin{array}{l}2027 \\
(46)\end{array}$ & $\begin{array}{l}22.2 \\
(3.2) \\
\end{array}$ & 1.0123 & $\begin{array}{l}856.4 \\
(12.7)\end{array}$ & $\begin{array}{l}2190 \\
(26)\end{array}$ & $\begin{array}{l}10.2 \\
(0.1) \\
\end{array}$ & 1.0068 \\
\hline $\begin{array}{c}\text { Piroxicam } \\
\text { (9) }\end{array}$ & Piroxicam & gel & 5 & $\begin{array}{l}712.4 \\
(6.1)\end{array}$ & $\begin{array}{l}2104 \\
(34)\end{array}$ & $\begin{array}{l}21.1 \\
(2.1)\end{array}$ & 1.0236 & $\begin{array}{l}710.6 \\
(17.1)\end{array}$ & $\begin{array}{c}2060 \\
(17)\end{array}$ & $\begin{array}{c}21.7 \\
(0.14)\end{array}$ & 1.0647 \\
\hline $\begin{array}{c}\text { Piroxicam } \\
(10)\end{array}$ & Piroxicam & $\begin{array}{l}\text { oint- } \\
\text { ment }\end{array}$ & 5 & $\begin{array}{c}1028.2 \\
(9.5)\end{array}$ & $\begin{array}{c}2874 \\
(52)\end{array}$ & $\begin{array}{l}28.2 \\
(2.4)\end{array}$ & 1.0617 & $\begin{array}{c}1018.5 \\
(24) \\
\end{array}$ & $\begin{array}{l}2880 \\
(30)\end{array}$ & $\begin{array}{c}27.9 \\
(0.12) \\
\end{array}$ & 1.0453 \\
\hline $\begin{array}{c}\text { Butapirazol } \\
\text { (11) }\end{array}$ & Phenylbenzene & $\begin{array}{l}\text { oint- } \\
\text { ment }\end{array}$ & 5 & $\begin{array}{l}1312 \\
(31)\end{array}$ & $\begin{array}{l}3167 \\
(19)\end{array}$ & \begin{tabular}{|c|}
35.7 \\
$(0.65)$
\end{tabular} & 1.0321 & $\begin{array}{l}1402 \\
(37)\end{array}$ & $\begin{array}{c}2886 \\
(43)\end{array}$ & $\begin{array}{l}41.26 \\
(0.19)\end{array}$ & 1.0115 \\
\hline
\end{tabular}

Figure 2 shows the results of mean positrons lifetime, lifetime of the long-lived component, and its intensity (for the distribution into two and three components). 


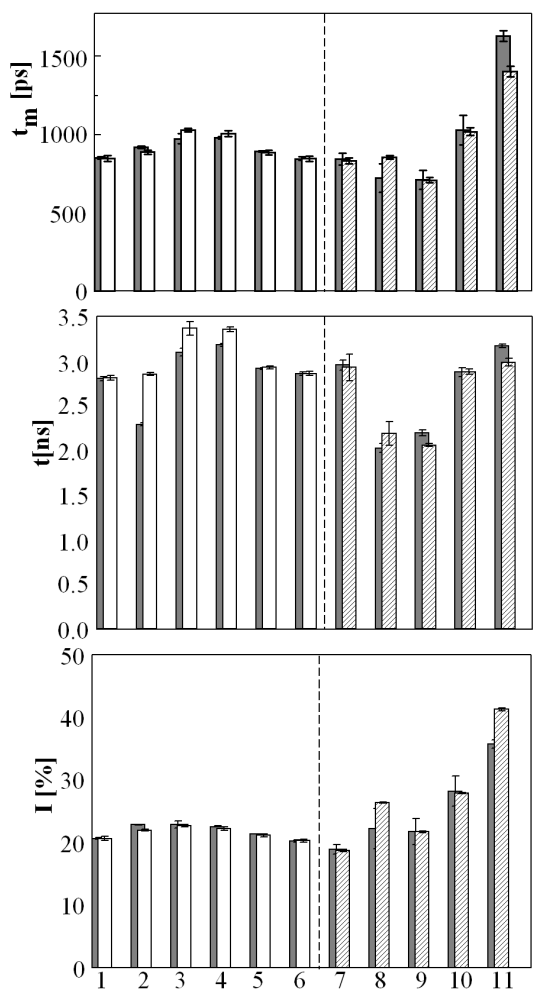

Fig. 2. Parameters of the positron lifetime spectrum in the investigated analgesic and antiphlogistic drugs. The bars on the left side concern parameters of spectra from deconvolution on two components; on the right side - from deconvolution on three components. The numbers of bars have been attributed to the names of respective drugs included in Table.

As it can be seen, in the group of drugs based on sodium salts of diclophenac (bars 1-6) the intensity of the component of the spectrum of positrons lifetimes, which corresponds to the annihilation of positrons from the state of ortho-Ps, are, in approximation, similar to one another, yet the very values of this lifetime themselves differ considerably from one another and depend on the manner of deconvolusion of the spectrum (two or tree components). This is obviously reflected in the values of mean positrons lifetime. As regards this group of drugs, the gels known under the trade names Olfen and Ratiogel, display the longest lifetimes of the ortho-Ps component. In the group of other drugs the ortho-Ps lives considerably shorter in preparations based on naproxen and piroxicam (bars 8 and 9). The bars marked with the number of 10 in Fig. 2 also, as a matter of fact, refer to piroxicam, but that in the form of ointment. It is evident, however, that both the values of mean positrons lifetime $\tau_{\mathrm{m}}$, the ortho-Ps lifetime $\tau$, as well as its intensity $I$, are clearly greater for piroxicam dissolved in a substance with the 
consistency of gel. Bars no. 11 show data describing the spectrum of positrons lifetimes for the drug in which the healing substance is butapirazol in the form of ointment. For these parameters both the ortho-Ps lifetime and its intensity take the greatest values.

According to the model proposed by Tao [22] and Eldrup et al. [23], the component of the longest lifetime $(\tau)$ connected with the annihilation of ortho-Ps in polymers and liquids is bounded with the mean radius of free volume $R$ by means of the relation:

$$
\tau_{3}=\lambda_{0}\left[1-\frac{R}{R+\Delta R}+(2 \pi)^{-1} \sin \frac{2 \pi R}{R+\Delta R}\right]^{-1},
$$

where $\lambda_{0}^{-1}=0.5 \mathrm{~ns}, \Delta R$ - a certain constant dependable on the shape of the free space, in which positron annihilates. For the spherical free space its value amounts to $0.1656 \mathrm{~nm}$.

Figure 3 presents the value of the radius of free volume (spherical) for the preparations under investigation, which were calculated from the formula (2). As it can be seen, mean radii of empty spaces in the drugs based on sodium salts of diclophenac are of the order of $0.8 \mu \mathrm{m}$ and, being approximately, the same.

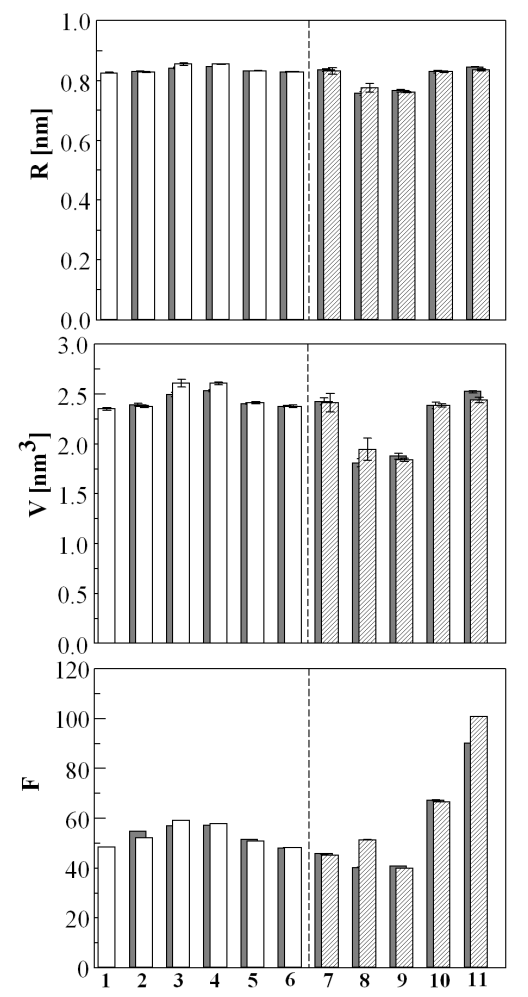

Fig. 3. Diagrams of radius of free volume $R$, free volume $V$, and parameters $F$ for investigated drugs. The numbers of bars have been attributed to the names of respective druds included in Table. 
The lowest values of the radii of the empty spaces are characteristic of gels of naproxen and piroxicam, whereas the highest - those of ointments of piroxicam and butapirazol.

Measurements of positrons lifetimes in the systems, where positron forms, allow assessing the so-called relative free volume $f$. This parameter is defined as follows:

$$
f=\frac{\left(V-V_{0}\right)}{V}
$$

where $V$ - the total macroscopic volume of the system, $V_{0}$ - the volume occupied by molecules of the system.

Wang et al. [24] as well as Kobayashi et al. [25] proposed a semi-empirical equation which can be applied to assess the values of this parameter on the basis of annihilation parameters of the positrons lifetimes spectrum.

$$
f=A \frac{4}{3} \pi R^{3} I_{3}=A F
$$

where $F=\frac{4}{3} \pi R^{3} I_{3}, A-$ a normalizing constant. According to Wang et al. [24] the value of this normalizing constant at room temperature is close to one.

Figure 3 shows the values of parameter $F$ for the investigated drugs. It can be seen that in the group of drugs based on diclophenac, the degree of filling up the space is the least in the medicaments Olfen and Ratiogel. In the other group of drugs the ointments of piroxicam and butapirazol are characterized by the least degree of filling up the space.

\section{Conclusions}

The following conclusions can be drawn upon the conducted research:

1. The longest ortho-Ps lifetimes of the investigated medical preparations occur in drugs having the consistency of gel, based on sodium salts of diclophenac, while the shortest - in drugs made on the basis of naproxen and butapirazol.

2. The highest intensities of ortho-Ps component of the spectrum of positrons lifetimes occur in drugs in the form of ointment.

3. The ointments of naproxen and piroxicam are characterized by the least degree of filling up the space.

\section{References}

[1] A. Baranowski, M. Dȩbowska, K. Jerie, L. Kurzeja. K. Hennek, J. Rudzińska-Girulska, Acta Phys. Pol. A 88, 43 (1995).

[2] K. Jerie, A. Baranowski, J. Gliński, K. Orzechowski, Acta Phys. Pol. A 95, 562 (1999).

[3] K. Jerie, A. Baranowski, J. Gliński, K. Orzechowski, Acta Phys. Pol. A 95, 569 (1999).

[4] K. Jerie, A. Baranowski, J. Gliński, K. Orzechowski, J. Przybylski, Acta Phys. Pol. A 99, 393 (2001). 
[5] K. Jerie, A. Baranowski, J. Przybylski, J. Gliński, in: Proc. 33rd Seminar on Positron Annihilation, Turawa 2001, Ed. K. Jerie, University of Opole, University of Wrocław, Opole 2001, p. 51.

[6] K. Ciesielski, A.L.Dawidowicz, T. Goworek, Acta Phys. Pol. A 95, 483 (1999).

[7] T. Goworek, J. Nucl. Radiochem. Sci. 1, 11 (2000).

[8] T. Goworek, T. Suzuki, E. Hamada, K. Kondo, Y. Ito, Chem. Phys. 255, 347 (2000).

[9] B. Jasińska, A.L. Dawidowicz, S. Radkiewicz, Acta Phys. Pol. A 99, 379 (2001).

[10] B. Jasińska, A.L. Dawidowicz, in: Proc. 34th Polish Seminar on Positron Annihilation, Turawa 2002, Ed. K. Jerie, University of Opole, University of Wrocław, Opole 2002, p. 39.

[11] T. Goworek, J. Wawryszczuk, R. Zaleski, Acta Phys. Pol. A 107, 608 (2005).

[12] T. Goworek, J. Wawryszczuk, R. Zaleski, Chem. Phys. Lett. 387, 433 (2004).

[13] W. Osoba, Acta Phys. Pol. A 95, 632 (1999).

[14] W. Osoba, Acta Phys. Pol. A 99, 447 (2001).

[15] J. Borek, W. Osoba, J. Polym. Sci. B, Polym. Phys. 34, 1903 (1996).

[16] A. Danch, W. Osoba, in: Proc. 33rd Seminar on Positron Annihilation, Turawa 2001, Ed. K. Jerie, University of Opole, University of Wrocław, Opole 2001, p. 117.

[17] J. Borek, W. Osoba, Acta Phys. Pol. A 88, 91 (1995).

[18] K. Ito, Y. Ujihira, T. Yamashita, K. Horie, Acta Phys. Pol. A 95, 551 (1999).

[19] Zs. Kajcsos, L. Liszkay, D. Duplâtre, L. Varga, K. Lázár, G. Pál-Borbély, H.K. Berger, L. Lohonyai, P. Caullet, J. Patarin, Acta Phys. Pol. A 99, 399 (2001).

[20] T. Hirade, Acta Phys. Pol. A 107, 615 (2005).

[21] R. Pietrzak, R. Szatanik, Acta Phys. Pol. A 107, 852 (2005).

[22] S. Tao, J. Chem. Phys. 56, 5499 (1972).

[23] M. Eldrup, D. Lightody, J. Sherwod, J. Chem. Phys. 63, 51 (1981).

[24] Y. Wang, H. Nakanishi, Y. Jean, T. Sandreczki, J. Polym. Sci. B, Polym. Phys. 28, 143 (1990).

[25] Y. Kobyashi, W. Zeng, E. Meyer, J. Mc Gervey, A. Jemison, R. Simha, Macromolecules 22, 2302 (1989).

[26] J. Kansy, Nucl. Instrum. Methods A 374, 235 (1996). 